\title{
THERE'S MORE TO THE PICTURE THAN MEETS THE EYE: A COMPARISON OF DOWNSIZING SURVIVORS WITH CHANGED AND UNCHANGED JOB CONTENT
}

\author{
J HELLGREN \\ K NÄSWALL \\ M SVERKE \\ Department of Psychology \\ Stockholm University
}

\begin{abstract}
Organisational downsizing has become a frequently used strategy to improve organisational effectiveness and competitive ability. The aim of this study was to examine the effects of downsizing on employee work stress, attitudes and well-being by comparing survivors who had their work situation changed as a function of the downsizing process with survivors whose situation remained unaffected. Longitudinal questionnaire data were obtained during the course of downsizing. Survivors with a changed work situation reported higher levels of work stress, less favourable work attitudes and more health complaints as compared to survivors who did not have their work situation changed.
\end{abstract}

\section{OPSOMMING}

Organisasie hersturkturering het 'n voortdurende strategie geword om organisasie effektiwiteit en kompeterende vermoëns te verbeter. Die doel van die studie was om die effek wat herstrukturering op werknemers se werkstres, gesindhede en welstand het, te ondersoek, deur oorblywende personeel wie se werksomgewing verander is deur hersturkturereing te vergelyk met oorblywende personeel wie se werksomgewings onveranderd gebly het. Longitudinale vraelysdata is ingesamel gedurende herstrukturering. Oorblywendes wie se werksomgewing verander het, het hoër vlakke van werkstres, minder gewensde gesindhede en meer gesondheidsprobleme getoon as die individue wie se situasie onveranderd gebly het.

In recent years there has been an increasing amount of organisational changes involving downsizing or closing and merging of facilities (Burke \& Cooper, 2000). Indeed, organisational downsizing through permanent layoffs and offers of early retirement has become one of the most frequently used strategies for improving effectiveness and competitive ability (Cameron, Freeman, \& Mishra, 1991; Kalimo, Taris, \& Schaufeli, 2003). Downsizing strategies may involve many different facets and angles but they all, by definition, contain methods of personnel reduction. Research has defined downsizing as "the planned elimination of positions or jobs" (Kets de Vries \& Balazs, 1997, p. 11), and emphasized that downsizing is a deliberate organisational decision aimed at systematically reducing the workforce through an intentionally instituted set of activities with the direct purpose of improving organisational efficiency and performance (Appelbaum, Simpson, \& Shapiro, 1987; Cameron et al., 1991).

Organisations engaged in downsizing, as well as other types of organisational change, often expect positive effects such as lower overhead costs, decreased bureaucracy, faster decision making processes, smoother communication, increased productivity, and better earnings (Kets de Vries \& Balazs, 1997). However, several studies have reached the conclusion that the postulated benefits of organisational downsizing are seldom achieved and that the negative side effects have severe consequences for the organisations' vitality and competitive ability (e.g., Beylerian \& Kleiner, 2003; Burke \& Nelson, 1998; Cascio, 1995, 1998; Devine, Reay, Stainton, \& Collins-Nakai, 2003; Kets de Vries \& Balazs, 1997; Pfeffer, 1998). Furthermore, the slimmed-down organisations are more likely to outsource specific tasks and to use an increased number of temporary workers in order to minimise the size of the core organisation (Pfeffer, 1997). Covin (1993) identified three aspects that characterise the downsizing process and distinguished it from other types of organisational change: First, the top management - with little or no employee participation - usually dictates the

Requests for copies should be addressed to: J Hellgren, jhn@psychology.su.se downsizing process. Second, downsizing efforts focus more on financial efficiency goals than human effectiveness goals. Third, people will be hurt; there is no "win-win" situation in a downsizing process.

Employees who manage to keep their jobs after organisational downsizing are often referred to as "survivors". In their review of the downsizing research, Kozlowski, Chao, Smith, and Hedlund (1993) concluded that the effectiveness of downsizing strategies is ultimately dependent on the reactions of the survivors of the process. Thus, the survivors' behaviour is critical for the slimmed organisation's effectiveness. Behavioural changes not only result from changes in the formal system or the normative structures, but are also influenced by changes in the cognitive and perceptual orientations of the individuals (Allen, Freeman, Russel, Reizenstein, \& Rentz, 2001; Chin \& Benne, 1994). This highlights the importance of the survivors' interpretation and perceptions of the downsizing process as well as the evaluation of their current position and status in the organisation.

An important observation in this respect is that the downsizing process may vary substantially between different organisations - and consequently also the definition of survivors. Unfortunately, however, research on how different types of survivors are affected by downsizing is limited. It is plausible that survivors who have been relocated or had their immediate work situation changed in terms of assigned work tasks and perceived obligations may react differently compared to survivors whose work situation is more or less the same as before the downsizing process. Employees who have been subject not only to the stress of potential job loss but also experience changes in job content, obligations and responsibilities, may perceive a higher level of uncertainty and tension in the work situation as compared with survivors who remain in their old familiar jobs. Previous research on organisational change suggests that uncertainty and lack of control are associated with higher levels of stress and impaired work attitudes (e.g., Ashford, 1988; Theorell, 2003; Terry \& 
Jimmieson, 1999, 2003). This is also in line with stress theory, which suggests that uncertainty and inability to predict the environment are stressful for the individual (e.g., Karasek \& Theorell, 1990; Lazarus \& Folkman, 1984).

Given this, it is important to shed light on the complex phenomenon of downsizing survivors. By distinguishing between different types of survivors research has the potential to provide insights that may prove valuable for the implementation of prevention and intervention strategies aimed at reducing the stress of downsizing survivors. The survivors investigated in the present study had all been given notice at an earlier stage in the process and then got lucky when applying for the limited number of jobs available in the organisation. Some of the survivors got their old jobs back while others got a new job with new job tasks and demands. This leaves us with two different groups of survivors, one where the survivors stayed in their old jobs and one where the survivors were relocated to other jobs or positions in the organisation. The present study is based on the assumption that the work climate may be worse for survivors who have had their work situation changed. In addition, survivors with changed work content may react with less favourable attitudes towards the job and the organisation as well as lower general well-being compared with survivors who remain in the same jobs as before the reorganisation.

Below, we first discuss some of the consequences associated with downsizing, before developing the arguments for the importance of not treating all victims of downsizing as one homogenous group, since downsizing may affect different kinds of survivors differently. Later sections in the article describe the research methods and present the results. Finally, the results are discussed and some limitations of the study are addressed.

\section{Downsizing and its consequences}

The individuals who are the most affected by downsizing are supposedly those who lose their jobs. Consequently, research studying the impact of downsizing has typically focused on the laid-off personnel (Kozlowski et al., 1993), or investigated possible organisational consequences, such as loss of crucial skills in human capital and disruption in organisational memory in terms of problem solving, competence and abilities (Kets de Vries \& Balazs, 1997). However, the fact that the most immediate effect of a downsizing process is a reduced workforce highlights the importance of systematic analyses of how downsizing affects the remaining personnel (i.e., the survivors). Indeed, a striking characteristic of previous research is the conclusion that organisational downsizing tends to have detrimental consequences for the employees who remain in the organisation (ArmstrongStassen, 2005; Beylerian \& Kleiner, 2003; Makawatsakul \& Kleiner, 2003). Although earlier studies have found negative relationships between downsizing experiences and job as well as organisational attitudes (e.g., Allen et al., 2001; Beylerian \& Kleiner, 2003; Devine et al., 2003; Davy, Kinicki \& Scheck, 1991; Hellgren, Sverke, \& Isaksson, 1999; Konovsky \& Folger, 1987; Paulsen et al., 2005; see also Kozlowski et al., 1993), most studies have treated survivors as one homogeneous group and typically contrasted them against employees who have been laid-off, or against employees not exposed to any organisational change.

There might, however, be more to the picture than meets the eye. Rather than treating downsizing survivors as a homogeneous group - and assuming they will react similarly with respect to work attitudes and well-being - it may be fruitful to distinguish between different types of survivors. An important distinction that can be made is the one between survivors with changed and unchanged work content. Survivors who have their work situation changed during organisational turmoil do not only have to cope with uncertainty and stress due to the organisational change as such, but also with uncertainty following that their immediate work environment is also being changed (Hellgren $\&$ Sverke, 2001).

It might be argued that survivors who have been relocated to other jobs or positions, or have had their work tasks changed, may perceive their work more negatively and experience more work stress, as manifested, for instance, in an increased workload, perceptions of role conflict and job insecurity (Hellgren, Sverke, \& van der Vliet, 2005). In the present study, two dimensions of workload were investigated. Quantitative role overload reflects the perception of having too many work tasks to do in available time, while qualitative role overload refers to the feeling of having too difficult work tasks to carry out in relation to skills and knowledge (Beehr, Walsh, \& Taber, 1976; Sverke, Hellgren, \& Öhrming, 1997). Role conflict, another type of work stress, concerns the experience of having to deal with conflicting terms, instructions, and/or demands in the work environment (Rizzo, House, \& Lirtzman, 1970).

Job insecurity is another frequently examined stressor in the context of organisational change and downsizing (De Witte, 1999; Sverke, Hellgren, \& Näswall, 2002). By definition, job insecurity contains elements of involuntary unpredictability about the future existence of the present job or of the future nature of the present job (Heaney, Israel \& House, 1994; Sverke et al., 2002). This in turn leaves the employee with an uncontrollable situation and, thus, job insecurity is stressful for the individual and can be characterized as a work stressor (Barling \& Kelloway, 1996). This study examines two aspects of job insecurity - quantitative and qualitative (Hellgren et al., 1999). Quantitative job insecurity refers to the worry of losing the job as such and being laid-off in the near future, whereas qualitative job insecurity reflects the worry or fear of losing - for the individual - important aspects of the job, such as job content, career opportunities, salary development, and work mates.

Since downsizing typically implies increased workload and uncertainty about the future, it could be expected that the employees' relation to and perceptions of the organisation change as well. This may be the case especially if the job content also has changed. It is therefore possible that survivors who experience a change in the job itself in combination with the organisational change react with more negative attitudes towards the job and the organisation, compared with survivors who keep their old jobs during the downsizing process. The present study also relies on theoretical research suggesting that changes in attitudinal constructs may be related to behavioural patterns and, hence, to work outcomes (Kanungo, 1982; Locke, 1976; Mowday, Steers, \& Porter, 1979).

The attitudinal constructs investigated in this study were job satisfaction, job involvement, organisational commitment, and turnover intention. Job satisfaction represents a general affective response to the overall job situation. Following Locke (1976, p. 1300), we define job satisfaction as "a pleasurable or positive emotional state resulting from the appraisal of one's job or job experience". In accordance with Kanungo (1982), job involvement is defined as an individual's cognitive or belief state of psychological identification with the job. Organisational commitment is defined as an attitude that describes the relative strength of an individual's identification and involvement in a particular organisation (Mowday et al., 1979). Finally, turnover intention reflects the individual's wish to voluntarily leave the organisation and search for another employer (Mobley, Griffeth, Hand, \& Meglino, 1979).

Many studies have documented that downsizing may also have detrimental consequences for survivors' health and wellbeing (e.g., Armstrong-Stassen, 1993, 1994; Brockner, 1990; 
Hellgren \& Sverke, 2001; Isaksson, Hellgren, \& Pettersson, 2000; Kozlowski et al., 1993). Again, however, little is known about differences in health outcomes between survivors with changed and unchanged work content. The present study investigates potential differences between the two groups of survivors in mental health complaints, physical health complaints, carry-over effects, and fatigue. In addition, the study tests for differences in sickness absenteeism, amount of doctors' visits, and consumption of medicine and alcohol. Again, given the increased uncertainty and stress that could be expected for survivors with changed job content, we expect the health-related consequences to be worse for this group as compared to survivors who remain in their old positions.

Previous research has suggested that health complaints and perceptions of different stressors may be under influence of gender and age (e.g., De Witte, 1999; Diener, Suh, Lucas \& Smith, 1999). In a review of the literature on subjective wellbeing, Diener et al (1999) concluded that depression is more prevalent among women and that women generally may be more prone to experience and express emotions. The authors also concluded that elderly people have a tendency to report higher negative emotions as compared to younger. In line with this, a study of contingent workers found that women reported more somatic complaints than men (Sverke, Gallagher \& Hellgren 2000). Previous studies have also reported age differences in self-rated stress and well-being (e.g., Mohr, 2000). Therefore, gender and age were used as covariates in the analyses in order to reduce the risk of overestimating the effects of survivor status on outcomes.

The proposition tested in this study is that survivors who experience changes in the work content would react with higher levels of work stress, lower levels of job and organisational attitudes, and more frequent experiences of negative health symptoms and behaviours as compared with job content survivors being unchanged.

\section{METHOD}

\section{Setting and participants}

Data for the study was collected at two time points in a large Swedish retail company undergoing major organisational downsizing. The reorganisation generated elimination of nearly 50 percent of the 1,570 white-collar employees working in the central administration. This sample is composed of the survivors of the downsizing, that is, 786 remaining employees at the company headquarters. Time 1 data were collected in the autumn of 1995, approximately six months after the reorganisation was initialised. Time 2 data was collected one year later. In both data collection waves, questionnaires were mailed to the employees' home addresses accompanied with a pre-paid, self-addressed envelope. A cover letter explaining the purpose of the study and assuring confidentiality was also included in the mail-outs. Participation in the study was entirely voluntary.

At Time 1 a total of 555 usable questionnaires were returned (71\%). In the second data collection questionnaires were only sent to those who responded at Time 1. During the course of the study another 62 employees had lost their jobs. Out of the 493 possible Time 2 respondents, 395 returned their questionnaires to the research team (80\%). After correction for internal attrition the effective sample was 391. The total longitudinal response rate for both data collection waves was $55 \%$ (for analysis of drop-outs and nonrespondents, see Hellgren \& Sverke, 2003). At Time 1 the mean age of the respondents was 48 years $(S D=9)$, the average organisational tenure 21 years $(S D=11)$, and women comprised $54 \%$ of the sample.

\section{Measures}

Unless stated otherwise responses on the study variables were obtained on a 5-point Likert scale anchored with 1 ("strongly disagree") and 5 ("strongly agree"). Negatively phrased items were reverse coded prior to construction of mean value indices.

Quantitative role overload was assessed with three items developed by Beehr et al. (1976). The reliability estimate (Cronbach's alpha) for the index was satisfactory (Time 1: 0,81 ; Time 2: 0,84). The three items reflecting qualitative role overload were developed by Sverke et al. (1997), and the reliability estimate was 0,65 at Time 1 and 0,64 at Time 2 . Role conflict was measured with three items taken from the Rizzo et al. (1970) scale. Reliability at Time 1 was 0,74 and at Time 2 0,73. The quantitative dimension of job insecurity was measured with three items (Time 1 and Time $2 \alpha=0,79$ ), and the qualitative dimension was assessed with four items (Time 1 and Time 2 $\alpha=0,77)$, developed by Hellgren et al. (1999).

Job satisfaction was assessed with three items adopted from Brayfield and Rothe (1951) and slightly modified by Hellgren, Sjöberg, and Sverke (1997). The reliability estimate at Time 1 was 0,88 and at Time 20,86 . Job involvement was measured with three items taken from Kanungo's (1982) ten-item scale (reliability estimates 0,69 and 0,70 , respectively). Four items from Allen and Meyer's (1990) eight-item scale were used to reflect employees' organisational commitment (alpha reliabilities were 0,74 and 0,71 , respectively). Turnover intention was captured with a three-item scale developed by Sjöberg and Sverke (1996), and the reliability estimates were 0,71 at Time 1 and 0,75 at Time 2 .

In order to assess mental health complaints, Goldberg's (1979) 12 -item version of the General Health Questionnaire (GHQ) was used. Participants rated (on a scale ranging from 0 "never" to 3 "always") how frequently they had experienced various symptoms (e.g., felt constantly under strain) over last weeks. The alpha reliabilities for the scale were 0,84 at both time points. Physical health complaints were measured using the Andersson (1986) scale and the reliability estimates were 0,67 for Time 1 and 0,73 for Time 2. Carry-over was measured with a three-item index constructed by Hovmark, Frisk Wollberg, and Nordqvist (1996), which reflects perceptions of work to leisure carry-over in terms of difficulty winding down after work and sleeping problems due to job related problems (e.g., "After work I often keep worrying about job-related problems"). Alpha reliabilities were 0,88 and 0,80 , respectively. Fatigue was assessed with a single item (Andersson, 1986) reflecting exhaustion and tiredness after work. Sickness absenteeism was assessed with one item developed for the purpose of this study. The item reflects the amount of days on sick leave during the past three months. Doctor's visits were tapped with one item reflecting the frequency of doctor's visits during the last 12 months. The response options were comprised into categories ranging from 1 (never) to 5 (more than six times) for this item, which was developed by Andersson (1986). Finally, the consumption of medicine and alcohol was assessed with four single items developed for the purpose of this study. The items reflect the frequency of medicine (pain-killers, sleeping pills, and tranquilizers, respective) and alcohol usage, and the response mode ranged from 1 (daily) to 4 (never) (the four items were reverse coded prior to analysis).

\section{Analysis}

The issue of changed or unchanged work content was assessed at Time 2 with a single item subsequently used as the category variable in the analyses $(n=191$ for the unchanged group and $n=200$ for the group who had their work content changed). Data was analyzed with three multivariate analyses of variance (MANCOVA), using the Time 1 levels of the variables as well as gender and age as covariates. The first analysis investigated differences between 
those with changed or unchanged job content in work stress experiences. The second analysis investigated differences in work-related attitudes, and the final one tested for group differences in the health outcomes. Paired t-tests were also used in order to check for mean differences over time within each group. The reason for this is to more easily understand what a significant univariate $\mathrm{F}$ implies in terms of an increase or decrease (according to the t-test) occurring for one of the survivor groups in the experience of stress and well-being over time.

\section{RESULTS}

There was a significant multivariate effect obtained for survivor status (unchanged/changed work content) in work stress $(\mathrm{F}[5,364]=8,75, \mathrm{p}<0,001)$. Follow-up univariate tests (see Table 1) revealed that Time 2 survivors with changed work content experienced higher levels of both quantitative and qualitative role overload as well as higher levels of role conflict as compared to survivors with an unchanged work situation. In contrast to this, the results also show that survivors with unchanged work content experienced more quantitative job insecurity as compared to survivors with changed work content. There were no group differences in the experience of qualitative job insecurity.

\section{TABLE 1}

MANCOVA TEST FOR DIFFERENCES IN WORK STRESS BETWEEN SURVIVORS WITH UNCHANGED AND CHANGED WORK CONTENT AFTER CONTROLLING FOR TIME 1 LEVELS

\begin{tabular}{|c|c|c|c|c|c|}
\hline Variable & Work status & $\begin{array}{c}\text { Mean } \\
\text { Time } 1\end{array}$ & $\begin{array}{c}\text { Mean } \\
\text { Time } 2\end{array}$ & Diffa & $\mathrm{Fb}^{\mathrm{b}}$ \\
\hline \multirow{2}{*}{$\begin{array}{l}\text { Role overload } \\
\text { (quantitative) }\end{array}$} & Unchanged & 3,31 & 3,24 & $-0,07$ & \multirow[t]{2}{*}{5,52 * } \\
\hline & Changed & 3,63 & 3,72 & $+0,09$ & \\
\hline \multirow{2}{*}{$\begin{array}{l}\text { Role overload } \\
\text { (qualitative) }\end{array}$} & Unchanged & 1,81 & 1,76 & $-0,05$ & \multirow{2}{*}{$15,30 * * *$} \\
\hline & Changed & 2,07 & 2,28 & $+0,21$ * * & \\
\hline \multirow[t]{2}{*}{ Role conflict } & Unchanged & 2,59 & 2,47 & $-0,12$ & \multirow[t]{2}{*}{$13,02 * * *$} \\
\hline & Changed & 3,05 & 3,04 & $-0,01$ & \\
\hline \multirow{2}{*}{$\begin{array}{l}\text { Job insecurity } \\
\text { (quantitative) }\end{array}$} & Unchanged & 2,72 & 3,04 & $+0,32 * *$ & \multirow[t]{2}{*}{13,90 * * * } \\
\hline & Changed & 3,31 & 2,86 & $-0,45 * * *$ & \\
\hline \multirow{2}{*}{$\begin{array}{l}\text { Job insecurity } \\
\text { (qualitative) }\end{array}$} & Unchanged & 3,09 & 2,65 & $-0,44$ ** * & \multirow[t]{2}{*}{2,90} \\
\hline & Changed & 3,14 & 2,61 & $-0,53 * * *$ & \\
\hline
\end{tabular}

aPaired t-test for mean level change within group over time.

bUnivariate F-test for differences between groups after controlling for gender, age and the initial levels of all variables $(\mathrm{df}=1,368)$.

${ }^{*} \mathrm{p}<0,05 ;{ }^{* *} \mathrm{p}<0,01 ;{ }^{* * *} \mathrm{p}<0,001, \mathrm{n}=183$ (unchanged) and 194 (changed)

In regard to the job and organisational attitudes the results showed a significant multivariate effect of survivor status (F $[4,373]=4.34, p<0,01$ ). The univariate tests (see Table 2) indicated that there was a difference between the two types of survivors only for job satisfaction, where survivors with changed work content reported less job satisfaction compared to survivors with a more stable job content. For job involvement, organisational commitment, and turnover intention there were no differences between the two groups of survivors.

Table 3 shows the results for the health outcomes. A significant multivariate effect was obtained between the survivor groups $(\mathrm{F}[10,344]=3,59, \mathrm{p}<0,001)$. The univariate results show that survivors with changed work content reported more mental health complaints as well as more physical health complaints compared with survivors who remained in the same job. They also reported more carry-over problems compared with the survivors in the non-changed condition. The same pattern also emerged for experiences of fatigue, that is, the survivors with changed work situations reported more frequent experiences of fatigue compared with survivors with unaffected work content. There were no group differences identified for sickness absenteeism or the amount of doctor's visits. In terms of consumption of medicine and alcohol there were no differences between the different types of survivors except for the usage of sleeping pills. Survivors with changed work content reported slightly higher consumption of sleeping pills compared with survivors remaining in the same job.

TABLE 2

MANCOVA TEST FOR DIFFERENCES IN WORK ATTITUDES BETWEEN SURVIVORS WITH UNCHANGED AND CHANGED WORK CONTENT AFTER CONTROLLING FOR TIME 1 LEVELS

\begin{tabular}{llcclc}
\hline Variable & Work status & $\begin{array}{c}\text { Mean } \\
\text { Time 1 }\end{array}$ & $\begin{array}{c}\text { Mean } \\
\text { Time } 2\end{array}$ & Diffa & $F^{\mathbf{b}}$ \\
\hline Job satisfaction & $\begin{array}{l}\text { Unchanged } \\
\text { Changed }\end{array}$ & 3,64 & 3,67 & $+0,03$ & $14,72^{* * *}$ \\
& & 3,47 & 3,23 & $-0,24^{* *}$ & \\
\multirow{2}{*}{ Job involvement } & Unchanged & 2,83 & 2,72 & $-0,11$ & 0,43 \\
& Changed & 2,84 & 2,73 & $-0,11$ & \\
Organizational & Unchanged & 3,07 & 2,99 & $-0,08$ & 0,69 \\
commitment & Changed & 2,98 & 2,87 & $-0,11$ & \\
Turnover & Unchanged & 2,03 & 2,01 & $-0,02$ & 3,67 \\
intention & Changed & 2,13 & 2,29 & $+0,16^{* *}$ & \\
\hline
\end{tabular}

aPaired t-test for mean level change within group over time.

bUnivariate F-test for differences between groups after controlling for gender, age and the initial levels of all variables $(\mathrm{df}=1,376)$.

${ }^{*} \mathrm{p}<0,05 ;{ }^{*} \mathrm{p}<0,01 ;{ }^{* * *} \mathrm{p}<0,001, \mathrm{n}=188$ (unchanged) and 196 (changed).

TABLE 3

MANCOVA TEST FOR DIFFERENCES IN HEALTH OUTCOMES BETWEEN SURVIVORS WITH UNCHANGED AND CHANGED WORK CONTENT AFTER CONTROLLING FOR TIME 1 LEVELS

\begin{tabular}{|c|c|c|c|c|c|}
\hline Variable & Work status & $\begin{array}{c}\text { Mean } \\
\text { Time } 1\end{array}$ & $\begin{array}{c}\text { Mean } \\
\text { Time } 2\end{array}$ & Diffa & $F^{b}$ \\
\hline \multirow{2}{*}{$\begin{array}{l}\text { Mental health } \\
\text { (GHQ) }\end{array}$} & Unchanged & 0,71 & 0,65 & $-0,06^{*}$ & \multirow[t]{2}{*}{10,28 ** } \\
\hline & Changed & 0,86 & 0,86 & 0,00 & \\
\hline \multirow[t]{2}{*}{ Physical health } & Unchanged & 1,88 & 1,85 & $-0,03$ & \multirow{2}{*}{3,92 * } \\
\hline & Changed & 2,07 & 2,09 & $+0,02$ & \\
\hline \multirow[t]{2}{*}{ Carry-over } & Unchanged & 2,43 & 2,30 & $-0,13$ * & \multirow[t]{2}{*}{14,62 ** * } \\
\hline & Changed & 2,79 & 2,87 & $+0,08$ & \\
\hline \multirow[t]{2}{*}{ Fatigue } & Unchanged & 2,87 & 2,63 & $-0,24$ * * & \multirow[t]{2}{*}{20,61 * * * } \\
\hline & Changed & 3,04 & 3,23 & $+0,19$ * * & \\
\hline \multirow{2}{*}{$\begin{array}{l}\text { Sickness } \\
\text { absenteeism }\end{array}$} & Unchanged & 1,00 & 0,94 & $-0,06$ & \multirow[t]{2}{*}{0,06} \\
\hline & Changed & 1,05 & 0,91 & $-0,14$ & \\
\hline \multirow{2}{*}{ Doctors' visits } & Unchanged & 2,19 & 2,06 & $-0,13$ & \multirow[t]{2}{*}{0,24} \\
\hline & Changed & 2,13 & 2,00 & $-0,13$ & \\
\hline \multirow[t]{2}{*}{ Painkillers } & Unchanged & 1,85 & 1,89 & $+0,04$ & \multirow[t]{2}{*}{1,39} \\
\hline & Changed & 1,93 & 1,86 & $-0,07$ & \\
\hline \multirow[t]{2}{*}{ Sleeping pills } & Unchanged & 1,10 & 1,05 & $-0,05$ & \multirow[t]{2}{*}{4,61 * } \\
\hline & Changed & 1,12 & 1,16 & $+0,04$ & \\
\hline \multirow[t]{2}{*}{ Alcohol } & Unchanged & 1,40 & 1,36 & $-0,04$ & \multirow[t]{2}{*}{2,57} \\
\hline & Changed & 1,60 & 1,61 & $+0,01$ & \\
\hline \multirow{2}{*}{ Tranquilizers } & Unchanged & 1,08 & 1,04 & $-0,04$ & \multirow[t]{2}{*}{3,17} \\
\hline & Changed & 1,08 & 1,11 & $+0,03$ & \\
\hline
\end{tabular}

aPaired t-test for mean level change within group over time.

bUnivariate F-test for differences between groups after controlling for gender, age and the initial levels of all variables $(\mathrm{df}=1,353)$.

${ }^{*} \mathrm{p}<0,05 ;{ }^{*} \mathrm{p}<0,01 ;{ }^{* *} \mathrm{*}<0,001, \mathrm{n}=177$ (unchanged) and 190 (changed) 


\section{DISCUSSION}

The purpose of the present study was to shed some light on the impact of changing working conditions among downsizing survivors' perceptions of work stress, job and organisational attitudes, and well-being. Several studies have documented the negative effects associated with downsizing, among employees being laid-off as well as among the downsizing survivors (e.g., Appelbaum, Close \& Klasa, 1999; Beylerian \& Kleiner, 2003; Brockner, 1990; Devine et al., 2003; Isaksson et al., 2000; Kalimo et al., 2003; Noer, 1993). This is crucial since the main purpose with organisational downsizing is to increase the organisation's effectiveness and competitive ability with the usage of fewer employees carrying out the same amount of work that was previously done by a larger workforce. This makes it likely that the survivors' workload increases (Hellgren \& Sverke, 2001; Kalimo et al., 2003), which in turn may have a negative impact on their health (Karasek \& Theorell, 1990). In order to reach the downsizing goals the organisation is dependent on the survivors, their attitudes and behaviour as well as their health and wellbeing (Covin, 1993; Kozlowski et al., 1993). If the employees feel betrayed or let down by the organisation they might perceive the psychological contract as violated, and thereby react with impaired attitudes and aversive behaviour. Consequently, it seems difficult to get this downsizing equation together, which might be one of the reasons why many organisations engaged in downsizing activities seem to repeat them over and over again (Pfeffer, 1998).

In line with this, the study tested the potential impact of changed working conditions for survivors - which likely is a reality for many survivors - in terms of experiences of work stress, attitudes and well-being in order to better understand the problems associated with downsizing. The results showed that there indeed were differences between survivors with changed and unchanged work content. In terms of quantitative job insecurity the results reveal that survivors with changed work content reported less fear of loosing their jobs compared with survivors remaining in the same job. This might indicate that survivors who have been relocated or assigned to new work tasks feel more secure about their future in the organisation, thus implying that changes of the job content may be interpreted as positive in terms of future possibilities and options in the organisation. It is possible that survivors who remain in the old positions or jobs fear for the future in the organisation to a greater extent than those assigned to new job conditions. The fact that the individual has been assigned new work tasks may reduce insecurity perceptions and thereby provide a stronger sense of control over the situation. This is in line with previous research, which suggests that control helps the individual to cope with stressful situations (e.g., Dekker \& Schaufeli, 1995; Theorell, 2003).

In all other cases where differences were obtained, the results, in accordance with predictions, showed that survivors who experienced changes in their work content were more negatively affected. The fact that downsizing survivors with changed work content reported higher levels in all work stress variables suggests not only the survivors in general are left with a higher workload, but also that survivors with new work tasks to carry out are even worse off. These findings are not only important for management striving for a more competitive organisation; they may also have implications for the individual in terms of health and well-being. It should also be noted that there were no difference in terms of qualitative job insecurity between the two types of survivors. This indicates, perhaps somewhat counter-intuitive, that the assignment of new work tasks or remaining in the old ones is unrelated to the worry of losing important job features.

The only attitude variable that was found to be associated with survivor status was job satisfaction. The results suggest that survivors with changed job content were less satisfied with their work situation. This finding further highlights the significance of taking changes of job content into account in order to better understand the impact of organisational changes involving termination of positions or jobs. One potential explanation for the result obtained may be that the survivors who were assigned new or different work tasks may experience a breach of their psychological contract with the organisation (Robinson, 1996) to a larger extent than those remaining in the same job. The fact that there were no differences in job involvement, organisational commitment, or turnover intention indicates that these attitudinal constructs are unaffected by changes in the work content among survivors. This, however, does not imply that the survivors' attitudes are unaffected by downsizing as such. On the contrary, Allen et al. (2001), in a longitudinal study of downsizing survivors, found that job involvement and organisational commitment were the attitudes most difficult to restore to their original levels. Also other studies have documented downsizing consequences for survivors job and organisational attitudes (e.g., Hellgren et al., 1999; Isaksson et al., 2000; Ketz de Vries \& Balazs, 1997; Noer, 1993). However, the results of the present study indicate that all survivors may react in a similar way, regardless of whether their work content has changed or not.

In terms of health related outcomes, the results showed that survivors with changed work content experienced more mental health complaints as well as more physical health complaints together with more over-spilling of work-related issues to everyday life as compared with survivors with unaffected work contents. The same scenario was true also for the experience of fatigue after the workday. These results again stress the importance of taking the issue of changed job content into account in order to better understand the psychological consequences facing downsizing survivors. The results indicate that the assignment of new or different work tasks may hamper survivors' possibilities to relax and unwind, and thereby also their possibilities to recover and reload the batteries during leisure time and weekends. This again may be attributed to less experiences of control (Karasek \& Theorell, 1990), and potential interpretations of psychological contract breach or violations (Robinson, 1996) among survivors assigned new work tasks. That is, despite the possibility of them feeling more secure in their new jobs, the workload and role conflict following the redesigning of the jobs may create elevated health complaints and carry-over effects. The higher consumption of sleeping pills may also be attributed to problems relaxing or sleeping generated by carry-over effects. It should be noted, however, that there were no differences obtained for absenteeism and doctors' visiting, which indicates that survivors with changed or unchanged work content may be equally affected in terms of being absent from the job as well as with respect to actively seeking help from a doctor. Also in terms of consumption of pharmaceutics and alcohol the results indicate that there are no major differences between the two groups of survivors.

A few limitations concerning the study need to be addressed. First, there may be other potential explanations for the differences between the two groups of survivors than changes of work content, like self-selection, attrition, and potential third variables that may have influenced the results. This study did not measure any underlying psychological mechanism behind the different survivors' experiences of stress, and therefore it is difficult to draw sound conclusions regarding the underlying reasons for the stress experienced. It might be that survivors with unchanged work situation experienced stress for other reasons not measured in this study, and therefore the interpretation of the results may be uncertain. Future research may benefit from focusing more on the psychological process determining the stress experience. Second, there was no measure reflecting whether the changes or non-changes in work content were voluntary or involuntary. There is a possibility that the results are inflated by the fact that change 
or continuity in work content could have been either welcomed or undesired by the survivors. Third, all data presented are based on self-reports and collected by means of questionnaires, which may have influenced the results. It is also possible that the results may have been shaped, at least partly, by personality characteristics (for instance, attribution style), which were not controlled for in the study. Another limitation concerns generalisability. Since this study was based on one organisation operating in a specific cultural context, it may be desirable to replicate the findings using different methods, in other organisations as well as in other cultural settings. Finally, the fact that the qualitative role overload measure showed reliability estimates slightly below the often recommended level $(0,70)$ may have influenced the results and the effects of survivor status on perceptions of qualitative role overload may be underestimated due to the rather high error component in the measure.

Despite these limitations, the results indicate that downsizing survivors' perceptions of changed work conditions seem to be important in relation to the their work stress experiences, attitudes, and well-being. This highlights the importance to differentiate between different types, or sub-groups, of survivors in order to better understand the consequences of organisational downsizing. These results also signify the importance of identifying groups of survivors who need special attention in terms of support and managerial activities in order to prevent the most negative consequences from happening. This is not least important in attempts to understand the psychological mechanisms involved in this kind of organisational change, both from an individual point of view in terms of health and well-being of the workforce and also from an organisational perspective with the ambition to optimize the possibilities to actually reach the downsizing goals.

\section{AUTHOR'S NOTE}

The research reported here was conducted within the framework of a project financed by the National Institute of Working Life, through the Joint Programme for Working Life Research in Europe (SALTSA) and Alecta. The data were collected with the financial support from the Swedish Council for Work Life Research, the KF Group, the Salaried Employees' Union, and the Cooperative Employees' Association.

\section{REFERENCES}

Allen, N. J. \& Meyer, J. P. (1990). The measurement and antecedents of affective, continuance and normative commitment to the organization. Journal of Occupational Psychology, 63, 1-18.

Allen, T. D., Freeman, D. M., Russell, J. E., Reizenstein, R. C. \& Rentz, J. O. (2001). Survivor reactions to organizational downsizing: Does time ease the pain? Journal of Occupational and Organizational psychology, 74, 145-164.

Andersson, K. (1986). Utveckling och prövning av ett frågeformulärsystem rörande arbetsmiljö och hälsotillstånd. Rapport 2: 1986, Yrkesmedicnska kliniken, Örebro.

Appelbaum, S. H., Close, G. T. \& Klasa, S. (1999). Downsizing: an examination of some successes and more failures. Management Decision, 37, 424-437.

Appelbaum, S., Simpson, R. \& Shapiro, B. T. (1987). Downsizing: The ultimate human resource strategy. Business Quarterly, $52,1-9$.

Armstrong-Stassen, M. (1993). Production workers reactions to a plant closing: The role of transfer, stress, and support. Anxiety, Stress and Coping: An International Journal, 6, 201-214.

Armstrong-Stassen, M. (1994). Coping with transition: A study of layoff survivors. Journal of Organizational Behavior, 15, 597-621.
Armstrong-Stassen, M. (2005). Coping with downsizing: A comparison of executive-level and middle managers. International Journal of Stress Management, 2, 117-141.

Ashford, S. J. (1988). Individual strategies for coping with stress during organizational transitions. Journal of Applied Behavioral Science, 24, 19-36.

Barling, J. \& Kelloway, E. K. (1996). Job insecurity and health: The moderating role of workplace control. Stress Medicine, 12, 253-259.

Beehr, T. A., Walsh, J. T. \& Taber, T. D. (1976). Relationship of stress to individually and organizationally valued states: Higher order needs as a moderator. Journal of Applied Psychology, 61, 41-47.

Beylerian, M. \& Kleiner, B. H. (2003). The downsized workplace. Management research News, 26, 97-108.

Brayfield, A. H. \& Rothe, H. F. (1951). An index of job satisfaction. Journal of Applied Psychology, 35, 307-311.

Brockner, J. (1990). Scope of justice in the workplace: How survivors react to co-worker layoffs. Journal of Social Issues, 46, 95-106.

Burke, R. J. \& Cooper, C. L. (2000). The organization in crisis: Downsizing, restructuring, and privatization. Oxford: Blackwell Publishers Inc.

Burke, R. J. \& Nelson, D. (1998). Mergers and acquisitions, downsizing, and privatization: A North American perspective. In M.K. Gowing, J.D. Kraft, \& J.C. Quick (Eds.), The new organizational reality: Downsizing, restructuring, and revitalization (pp. 21-54). Washington, DC: American Psychological Association.

Cameron, K., Freeman, S. \& Mishra, A. (1991). Best practices in white-collar downsizing: Managing contradictions. Academy of Management Executive, 5, 57-73.

Cascio, W. F. (1995). Whither industrial and organizational psychology in a changing world of work. American psychologist, 11, 928-939.

Cascio, W. F. (1998). Learning from outcomes: Financial experiences of 311 firms that have downsized. In M.K. Gowing, J.D. Kraft, \& J.C. Quick (Eds.), The new organizational reality: Downsizing, restructuring, and revitalization (pp. 21-54). Washington, DC: American Psychological Association.

Chin, R. \& Benne, K. D. (1994). General strategies for effective changes in human systems. In French, Bell, \& Zawacki. Organizational development and transformation. Illinois, Irwin, Burr Ridge.

Covin, T. J. (1993). Managing workforce reduction: A survey of employee reactions and implications for management consultants. Organizational Development Journal, 11, 67-76.

Davy, J. A., Kinicki, A. J. \& Scheck, C.L. (1991). Developing and testing a model of survivors responses to layoffs. Journal of Vocational Behavior, 38, 302-317.

Devine, K., Reay, T., Stainton,L. \& Collins-Nakai, R. (2003). Downsizing outcomes: better a victim than a survivor? Human Resource Management, 42, 109-124.

De Witte, H. (1999). Job insecurity and psychological well-being: Review of the literature and exploration of some unresolved issues. European Journal of Work and Organizational Psychology, 8, 155-177.

Diener, E., Suh, E. M., Lucas, R. E. \& Smith, H. L. (1999). Subjective well-being: Three decades of progress Psychological Bulletin, 25, 276-302.

Dekker, S .W. A. \& Schaufeli, W. B. (1995). The effects of job insecurity on psychological health and withdrawal: A longitudinal study. Australian Psychologist, 30, 57-63.

Goldberg, D. (1979). Manual of the general health questionnaire. London: NFER Nelson.

Heaney, C. A., Israel, B. A. \& House, J. S. (1994). Chronic job insecurity among automobile workers: Effects on job satisfaction and health. Social Science and Medicine, 38, 1431-1437.

Hellgren, J., Sjöberg, A. \& Sverke, M. (1997). Intention to quit: Effects of job satisfaction and job perceptions, in F. Avallone, J. Arnold, \& K. de Witte (Eds.), Feelings work in Europe (pp. 415-423). Milano: Guerini. 
Hellgren, J. \& Sverke, M. (2001). Unionized employees' perceptions of role stress and fairness during organizational downsizing: Consequences for job satisfaction, union satisfaction and well-being. Economic and Industrial Democracy, 22, 543-567.

Hellgren, J. \& Sverke, M. (2003). Does job insecurity leads to impaired well-being or vice verca? Estimation of crosslagged effects using latent variable modeling. Journal of Organizational Behavior, 24, 215-236.

Hellgren, J., Sverke, M. \& Isaksson, K. (1999). A two-dimensional approach to job insecurity: Consequences for employee attitudes and well-being. European Journal of Work and Organizational Psychology, 8, 179-195.

Hellgren, J., Sverke, M. \& van der Vliet, C. (2005). The union side of downsizing: Investigating members' union attitudes. In $\mathrm{H}$. De Witte (Ed.), Job insecurity, union involvement and union activism (pp. 117-133). Aldershot: Ashgate.

Hovmark, S., Frisk Wollberg, E. \& Nordqvist, S. (1996). A longitudinal study of health complaints in professional computer work: Effects of computer-aided design. International Journal of Human-Computer Interaction, 4, 401-420.

Isaksson, K., Hellgren, J. \& Pettersson, P. (2000). Repeated downsizing: Attitudes and well-being for surviving personnel in a Swedish retail company. In K. Isaksson, C. Hogstedt, C. Eriksson, \& T. Theorell (Eds.), Health Effects of the New Labour Market. New York: Plenum.

Kalimo, R., Taris, T. W. \& Schaufeli, W. B. (2003). The effects of past and anticipated future downsizing on survivor wellbeing: An equity perspective. Journal of Occupational Health Psychology, 2, 91-109.

Kanungo, R. N. (1982). Measurement of job and work involvement. Journal of Applied Psychology, 67, 341-349.

Karasek, R. A. \& Theorell, T. (1990). Healthy work: Stress, productivity, and the reconstruction of working life. New York: Basic Books.

Kets de Vries, M. F. R. \& Balazs, K. (1997). The downside of downsizing. Human Relations, 50, 11-50.

Konovsky, M. \& Folger, R. (1987). Relative effects of procedural and distributive justice on employee attitudes. Representative research in social psychology.

Kozlowski, S., Chao, G., Smith, E. \& Hedlund, J. (1993). Organizational downsizing: Strategies, interventions and research implications. In C.L. Cooper \& I.T. Robertson (Eds.), International review of industrial and organizational psychology, Vol. 8 (pp. 263-332). New York: Wiley.

Lazarus, R. S. \& Folkman, S. (1984). Stress appraisal and coping. New York: Springer.

Locke, E. A. (1976). The nature and causes of job satisfaction. In M. Dunnette (Ed.), Handbook of industrial and organizational psychology (pp. 1297-1349). Chicago: Rand McNally.

Makawatsakul, N. \& Kleiner, B. H. (2003). The effect of downsizing on morale and attrition. Management Research News, 26, 52-62.

Mohr, G. B. (2000). The changing significance of different stressors after the announcement of bankruptcy: A longitudinal investigation with special emphasis on job insecurity. Journal of Organizational Behavior, 21, 337-359.
Mowday, R. T., Steers, R. M. \& Porter, L. W. (1979). The measurement of organizational commitment. Journal of Vocational Behavior, 14, 224-247.

Mobley, W. H, Griffeth, R. W, Hand, H. H. \& Meglino, B. M. (1979). Review and conceptual analysis of the employee turnover process. Psychological Bulletin, 86, 493-522.

Noer, D. (1993). Healing the wounds: Overcoming the trauma of layoffs and revitalizing downsized organizations. San Francisco: Jossey-Bass.

Paulsen, N., Callan, V. J., Grice, T. A., Rooney, D., Gallois, C., Jones, E., Jimmieson, J. N. \& Bordia, P. (2005). Job uncertainty and personal control during downsizing: A comparison of survivors and victims. Human relations, 58, 463-496.

Pfeffer, J. (1997). New directions for organization theory: Problems and prospects. New York: Oxford University Press.

Pfeffer, J. (1998). The human equation: Building profits by putting people first. Boston, MA: Harvard University Press.

Rizzo, J. R., House, R. J. \& Lirtzman, S. I. (1970). Role conflict and ambiguity in complex organizations. Administrative Sciences Quarterly, 15, 150-163.

Robinson, S. L. (1996). Trust and breach of the psychological contract. Administrative Science Quarterly, 41, 574-599.

Sjöberg, A. \& Sverke, M. (1996). Predicting turnover intention among nurses: The role of work values, in V.V. Baba (Ed.), Work values and behaviour: Research and applications (pp. 213223). Montréal: International Society for the Study of Work and Organizational Values.

Spector, P. E. (1986). Perceived control by employees: A metaanalysis of studies concerning autonomy and participation at work. Human Relations, 39, 1005-1016.

Sverke, M., Gallagher, D. G. \& Hellgren, J. (2000). Alternative work arrangements: Job stress, well-being and proorganizational attitudes among employees with different employment contracts. In K. Isaksson, C. Hogstedt, C. Eriksson, \& T. Theorell (Eds.), Health effects of the new labour market (pp. 145-167). New York: Plenum.

Sverke, M. \& Hellgren, J. (2002). The nature of job insecurity: Understanding employment uncertainty on the brink of a new millennium. Applied Psychology: An International Review, $51,23-42$.

Sverke, M., Hellgren, J. \& Näswall, K. (2002). No security: A meta-analysis and review of job insecurity and its consequences. Journal of Occupational Health Psychology, 3, 242-264.

Sverke, M., Hellgren, J. \& Öhrming, J. (1997). Hospital corporatization: How are nurses' job perceptions and workrelated attitudes affected?. Reports from the Department of Psychology, Stockholm University, 1997, No. 839.

Theorell, T. (2003). To be able to exert control over one's own situation: A necessary condition for coping with stressors. In J. Campbell Quick \& L. E. Tetrick. (Eds.), Handbook of occupational health psychology (pp. 201-219). Washington, DC: American Psychological Association.

Terry, D. J. \& Jimmieson, N. L. (1999). Work control and employee well-being: A decade review. International Review of Industrial and Organizational Psychology, 14, 95-148.

Terry, D. J. \& Jimmieson, N. L. (2003). A stress and coping approach to organizational change: Evidence from three field studies. Australian Psychologist, 38, 92-101. 